\title{
CHEMICAL ELEMENTS ANALYSIS OF THE SOIL AT AN URBANIZATION GRADIENT IN THE ATLANTIC FOREST
}

Thaís Jorge de Vasconcellos ${ }^{2}$ ๑, Nattacha dos Santos Moreira ${ }^{2} \odot$, Ramon Silva dos Santos ${ }^{3}$,

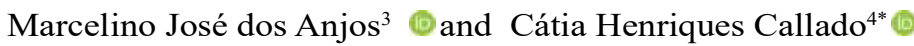

\footnotetext{
${ }^{1}$ Received on 05.03.2020 accepted for publication on 20.09.2020.

${ }^{2}$ Universidade do Estado do Rio de Janeiro, Programa de Pós-Graduação em Biologia Vegetal, Rio de Janeiro, RJ - Brasil. E-mail: $<$ thaisjv@yahoo.com.br> and <nattacha.moreira@gmail.com>.

${ }^{3}$ Universidade do Estado do Rio de Janeiro, Departamento de Física Aplicada e Termodinâmica, Rio de Janeiro, RJ - Brasil. E-mail: $<$ ramonziosp@yahoo.com.br>and <marcelin@uerj.br> .

${ }^{4}$ Universidade do Estado do Rio de Janeiro, Departamento de Biologia Vegetal, Rio de Janeiro, RJ - Brasil. E-mail: <catia.callado@gmail. com>.

*Corresponding author.
}

\begin{abstract}
The Atlantic Forest is home to the largest urban centers in Brazil, which modify various aspects of the natural quality of this forest. Soil chemical elements from three different sites in the Atlantic Forest in the state of Rio de Janeiro were analyzed: (1) the best-preserved remnant of Atlantic Forest in the state; (2) the largest urban forest in the world; and (3) an arboretum along the main vehicle route in the second-largest city in Brazil. Energy dispersive X-ray fluorescence (EDXRF) analysis detected sixteen chemical elements including nutrient components and potentially toxic elements. The urban soil had a higher concentration of heavy metals. There was a significant concentration gradient of copper and lead from the urban site to the furthest forest site. We emphasize that the results indicate potential negative consequences for the conservation of forests and wildlife of state of Rio de Janeiro.
\end{abstract}

Keywords: Soil contamination, Urban pollution, Urban soil

\section{ANÁLISE QUÍMICA ELEMENTAR DO SOLO EM UM GRADIENTE DE URBANIZAÇÃO NA FLORESTA ATLÂNTICA}

RESUMO - A Mata Atlântica abriga os maiores centros urbanos do Brasil e esses centros modificam vários aspectos da qualidade natural dessa floresta. Neste estudo, elementos químicos do solo em três diferentes locais da Mata Atlantica no Estado do Rio de Janeiro foram analisados: (1) o remanescente mais bem preservado de Mata Atlântica no Estado do Rio de Janeiro, (2) a maior floresta urbana do mundo, e (3) um arboreto junto à principal rota de veículos da segunda maior cidade do Brasil. A análise de Fluorescência de Raios X por Dispersão de Energia detectou dezesseis elementos químicos, entre componentes de nutrientes e elementos potencialmente tóxicos. O solo urbano apresentou maior concentração de metais pesados. $O$ cobre e o chumbo exibiram um gradiente de concentração significativo do sítio urbano ao sítio florestal mais distante dele. Destacamos que os resultados encontrados podem ter consequências negativas para a conservação das florestas e da fauna silvestre do Estado do Rio de Janeiro.

Palavras-Chave: Contaminação do solo, Poluição urbana, Solo urbano

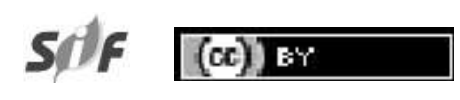

Revista Árvore 2021;45:e4504

http://dx.doi.org/10.1590/1806-908820210000004 


\section{INTRODUCTION}

The composition of soil surface layer may be significantly affected by elements from its natural constitution or by anthropogenic sources (KabataPendias 2011; Tume et al., 2017; Rodríguez-Eugenio et al., 2018). Urban soils are strongly affected by anthropogenic activities and high concentrations of heavy metals have been found at these sites (Wei and Yang, 2010; Lopes et al., 2015; Tume et al., 2018).

The industrialization and urbanization have been responsible for an increase in heavy metal concentrations in the environment (Nagajyoti et al., 2010; Zhu et al., 2013). After being released into the atmosphere, the main destination of these pollutants is the soil (KabataPendias, 2011). Unlike organic contaminants, which are oxidized by microorganisms, heavy metals do not undergo degradation and persist in the environmental for a long period of time (Wuana and Okieimen, 2011; Zhu et al., 2013; Romero-Freire et al., 2016).

The concentration of a given chemical element and its bioavailability in the soil depend on the proximity to its emission source, its chemical form and its interaction with the other constituents of the soil (Pierangeli et al., 2004; Kabata-Pendias, 2011). Upon entering the soil of forest ecosystems, pollutants can directly affect plants and/or threaten the functioning, composition and structure of the ecosystem itself, as well as interfere with several processes related to nutrient cycling (Furlan et al., 2008; Mahajan et al., 2019; Małkowski et al., 2019).

Although seemingly isolated and protected, forest remnants enclaved by, or close to, urban centers are exposed to pollution (Hernandez et al., 2003; RodríguezEugenio et al., 2018). In this context, the Atlantic Forest stands out by the fact that the largest urban centers and circa $60 \%$ of population of Brazil are situated within this biome (Scarano and Ceotto, 2015). The Atlantic Forest is recognized as one of the most threatened biomes on earth because the loss of most of its original distribution, continued devastation of its current forest remnants and proximity to pollution sources (Joly et al., 2014; Rezende et al., 2018).

In this study, we compared the soils from two forest remnants and from one planted area in the urban center of the city of Rio de Janeiro, all of them in the Atlantic Forest domain. Our objective was to address the following questions: (1) Are there significant differences in composition and chemical concentration of the elements found in the study sites soil? (2) Is it possible to observe anthropogenic contributions of potentially toxic chemical elements to the forest remnants soil? And (3) If so, are there any concentration gradients of potentially toxic chemical elements in relation to a pollution source proximity?

\section{MATERIALS AND METHODS}

Three sampling sites were chosen in the metropolitan area of Rio de Janeiro State, Brazil (Figure 1). Two of the sampling points were located in forest remnants of Atlantic Forest: Reserva Biológica do Tinguá (TINGUÁ - $22^{\circ} 34.951^{\prime} \mathrm{S}, 043^{\circ} 26.248^{\prime} \mathrm{W}$ ), the best-preserved remnant of Atlantic Forest in Rio de Janeiro State, and Parque Estadual da Pedra Branca (PEPB - $22^{\circ} 56.244^{\prime}$ $\left.\mathrm{S}, 043^{\circ} 26.102^{\prime} \mathrm{W}\right)$, the largest urban forest in World. The third sampling point was in the urban center: the arboretum of Fundação Oswaldo Cruz (FIOCRUZ - $22^{\circ}$ 52.335' S, $\left.043^{\circ} 14.704^{\prime} \mathrm{W}\right)$ Manguinhos campus, that is alongside the main vehicular route of the second largest city in Brazil. The urban site (FIOCRUZ) is located at sea level, because of this, we have selected regions up to 200 meters above sea level in forest sites (PEPB and TINGUÁ). It is worth mentioning that none of the forest sites is located on a hillside or with a steep slope. TINGUÁ and PEPB are located approximately $50 \mathrm{~km}$ and $26 \mathrm{~km}$ from the urban site, FIOCRUZ, respectively.

Five sampling points were selected at each study site and five soil samples took from each of these points. Soil samples were collected at soil layers 0 (topsoil), at 0-3 cm depth, at regular intervals of $1 \mathrm{~m}$. Only the soils of the forest sites had a layer of litter (approximately 4 $\mathrm{cm})$. As it is an arboretum, the soil of the urban site is continuously swept and did not accumulate litter close to the collection points. Thus, we opted to remove all litter before the actual soil collection at the two sampled forest sites. The soil samples were dried, homogenized and sieved with a 325 mesh $(44 \mu \mathrm{m})$. Next, $500 \mathrm{mg}$ soil aliquots were pressed at a pressure of $2.32 \times 10^{8}$ $\mathrm{Pa}$ for 15 minutes in order to obtain tablets of $2.5 \mathrm{~cm}$ in diameter, $1.0 \pm 0.5 \mathrm{~mm}$ thickness and at a density of $100 \mathrm{mg} / \mathrm{cm}^{2}$ (Anjos el al., 2000; Santos et al., 2019). All samples were prepared in triplicates.

The soil samples were analyzed by energy dispersive X-ray fluorescence (EDXRF). The XRF system was equipped with an X-ray tube (Mini-X by Amptek) with a silver anode (40 kV and $200 \mu \mathrm{A}$ maximum voltage and current) and an SDD detector (Silicon Drift Detector),

\section{Revista Árvore 2021;45:e4504}




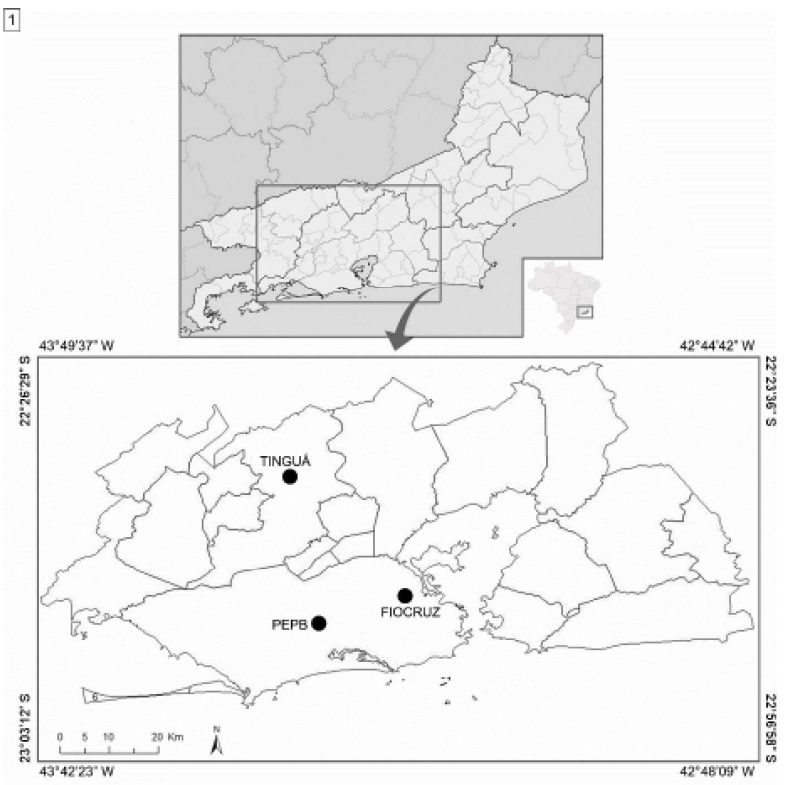

Figure 1 - Study sites in the metropolitan area of Rio de Janeiro State, Brazil. TINGUÁ: Reserva Biológica do Tinguá. PEPB: Parque Estadual da Pedra Branca. FIOCRUZ: Fundação Oswaldo Cruz.

Figura 1 - Sitios de estudo na região metropolitana do Estado do Rio de Janeiro, Brasil. TINGUÁ: Reserva Biológica do Tinguá. PEPB: Parque Estadual da Pedra Branca. FIOCRUZ: Fundação Oswaldo Cruz

model XR-100SDD (Amptek), with $500 \mu \mathrm{m}$ and 25 $\mathrm{mm} 2$ Si-thickness and area, and FWHM of about 125 $\mathrm{eV}$ at $5.9 \mathrm{keV}$. Two different experimental conditions were used in the analysis of soil samples. The first experimental condition was used for a better excitation of the low $\mathrm{Z}$ elements ( $\mathrm{S}$ to $\mathrm{Mn} \mathrm{K}$-lines and Ba L-lines), using $15 \mathrm{kV}, 100 \mu \mathrm{A}$ and an acquisition time of 200 $\mathrm{s}$. The second experimental condition for excitation of the high atomic number elements ( $\mathrm{Fe}$ to $\mathrm{Sr} \mathrm{K}$-lines and $\mathrm{Pb}$ L-lines), using $35 \mathrm{kV}, 100 \mu \mathrm{A}, 500 \mathrm{~s}$ and $\mathrm{a} \mathrm{TiO}^{2}$ filter. All experiments were performed under normal atmospheric conditions in room temperature. All XRF spectra were processed using the software PyMCA (Python Multichannel Analyzer) (Solé et al., 2007). In this study the elemental concentrations were obtained following the procedure developed by Anjos et al. (2000).

To checking the precision and the accuracy of the EDXRF system we carried out the elemental analysis of a Certified Reference Material: IAEA-SL-1 (Trace and minor elements in lake sediment). The reference material samples were prepared in the same way as soil samples. The relative errors were lower than $14 \%$. The results obtained for SL-1 were in good agreement with the comparative values certificate previously obtained, indicating the method provides comparable results.

Statistical analyses were performed using the software STATISTICA 7.0. Data were tested for normality and homoscedasticity using Shapiro-Wilk and Levene tests, respectively. Comparisons of parametric data were performed using ANOVA (one-way) test, followed by the Tukey post-test, while comparisons of non-parametric data were done with the Kruskal-Wallis test. All tests were evaluated using a 95\% confidence interval (Zar, 2010).

\section{RESULTS}

Sixteen chemical elements were detected in all the study sites: potassium, calcium, titanium, chromium, manganese, iron, nickel, copper, zinc, gallium, bromine, rubidium, strontium, zirconium, niobium and lead. Significant differences were detected among the three sites for all elements except for iron and gallium (Figure 2). Potassium and manganese concentrations were higher in the soil of the forest remnants (TINGUÁ and PEPB) than in the urban soil (FIOCRUZ), although the difference in manganese between TINGUÁ and FIOCRUZ was not significant (Figure 2).

Bromine and titanium concentrations differed significantly between forest remnants, TINGUÁ and PEPB, with higher values in PEPB, although neither forest remnant site differed significantly from the urban site (FIOCRUZ) (Figure 3). Rubidium concentrations were significantly different among three sites (Figure 3 ), with the highest concentration being in PEPB and the lowest in FIOCRUZ. Chromium concentration was significantly lower in PEPB than in the other two sites (Figure 3), but it did not differ significantly between FIOCRUZ and TINGUÁ (Figure 3). The same relationship was observed for calcium and strontium (Figure 4). TINGUÁ soil differed significantly from the other sites in zirconium and niobium concentrations (Figure 4), which were lower and higher, respectively. The concentrations of these elements did not differ significantly between PEPB and FIOCRUZ.

The soil of FIOCRUZ has statistically higher nickel concentrations than the soil of TINGUÁ (Figure 5). FIOCRUZ also had significantly higher copper, zinc and lead concentrations (Figure 5) when compared to the

Revista Árvore 2021;45:e4504 

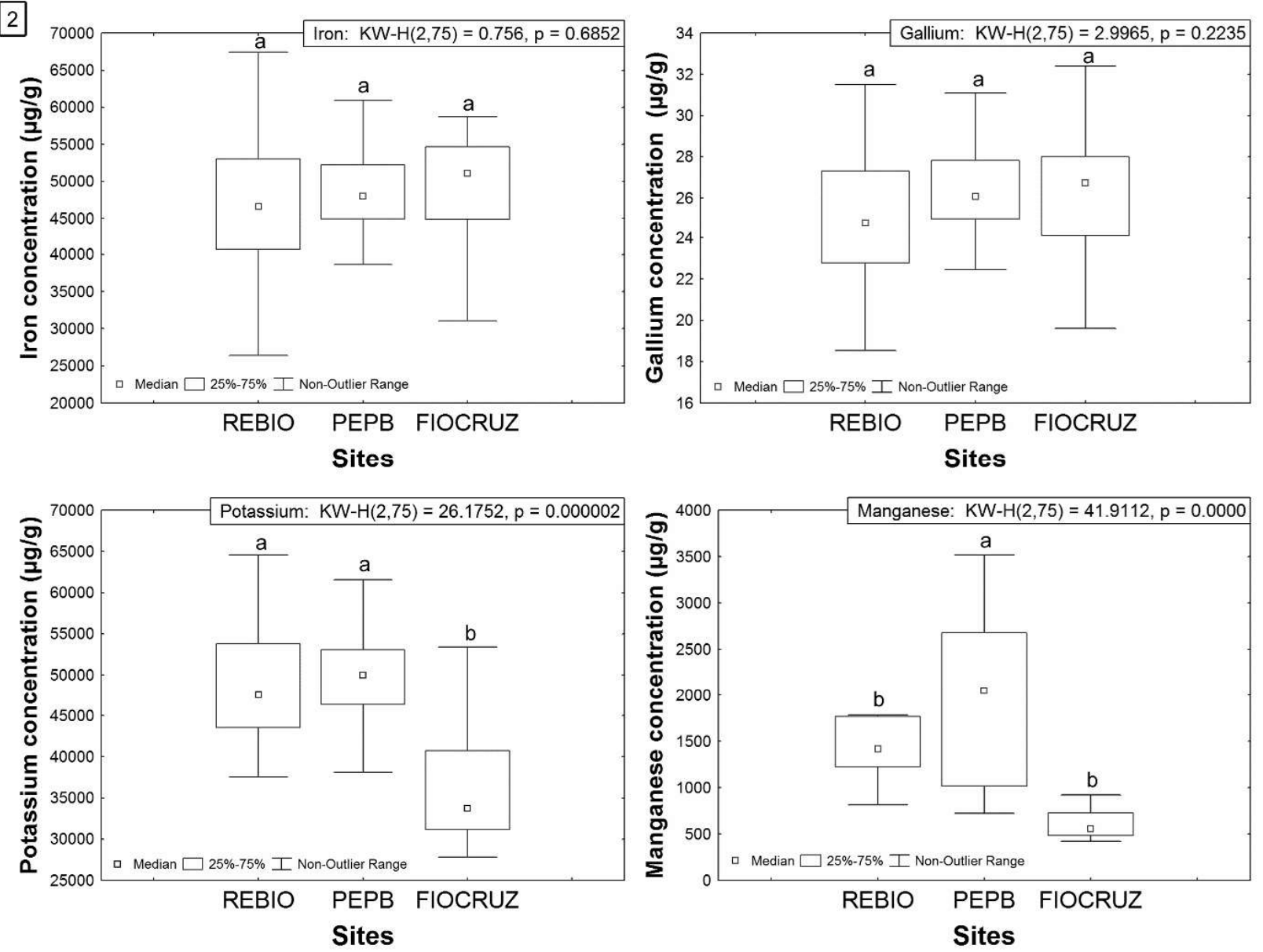

Figure 2 - Box-plots of iron, gallium, potassium and manganese soil concentrations of the three study sites. The letters above the box indicate the results of ANOVA and Kruskal-Wallis tests. Different letters indicate statistics differences $* \mathrm{p}<0.05$.

Figura 2 - Box-plots de concentrações de ferro, gálio, potássio e manganês no solo dos três locais de estudo. As letras acima da caixa indicam os resultados dos testes ANOVA e Kruskal-Wallis. Letras diferentes indicam diferenças estatísticas * $p<0,05$

other two studied sites (Figure 5). It is worth noting that zinc concentration did not differ significantly between forest remnants (TINGUÁ and PEPB), while copper and lead concentrations were significantly higher in PEPB than in TINGUÁ (Figure 5).

Copper and lead concentrations were significantly different among three studied sites (Figure 5). These elements exhibited a concentration gradient from the urban site to the furthest forest site TINGUÁ, with FIOCRUZ having the highest concentrations of these two elements, followed by PEPB and then TINGUÁ. The same concentration gradient pattern was observed for zirconium, nickel and zinc, although significant differences were not always detected among these sites (Figures 4 and 5).

\section{DISCUSSION}

This study showed that higher concentrations of potassium and manganese in the forest remnants soils, and that higher concentrations of heavy metals, such as nickel, chromium, copper, zinc and lead, are in the urban site, indicating the negative effects of urban anthropic activities. High soil concentrations of heavy metals have been identified as a risk to the health of living organisms and, consequently, to biodiversity conservation (e.g.: Dai et al., 2004; Freitas et al., 2015). However, the biodisponibility of chemical elements will depend on the total values, the chemical forms in which the interaction and the other components of the soil (Pierangeli et al., 2004; Guilherme et al., 2005; Appel et al., 2008).

\section{Revista Árvore 2021;45:e4504}



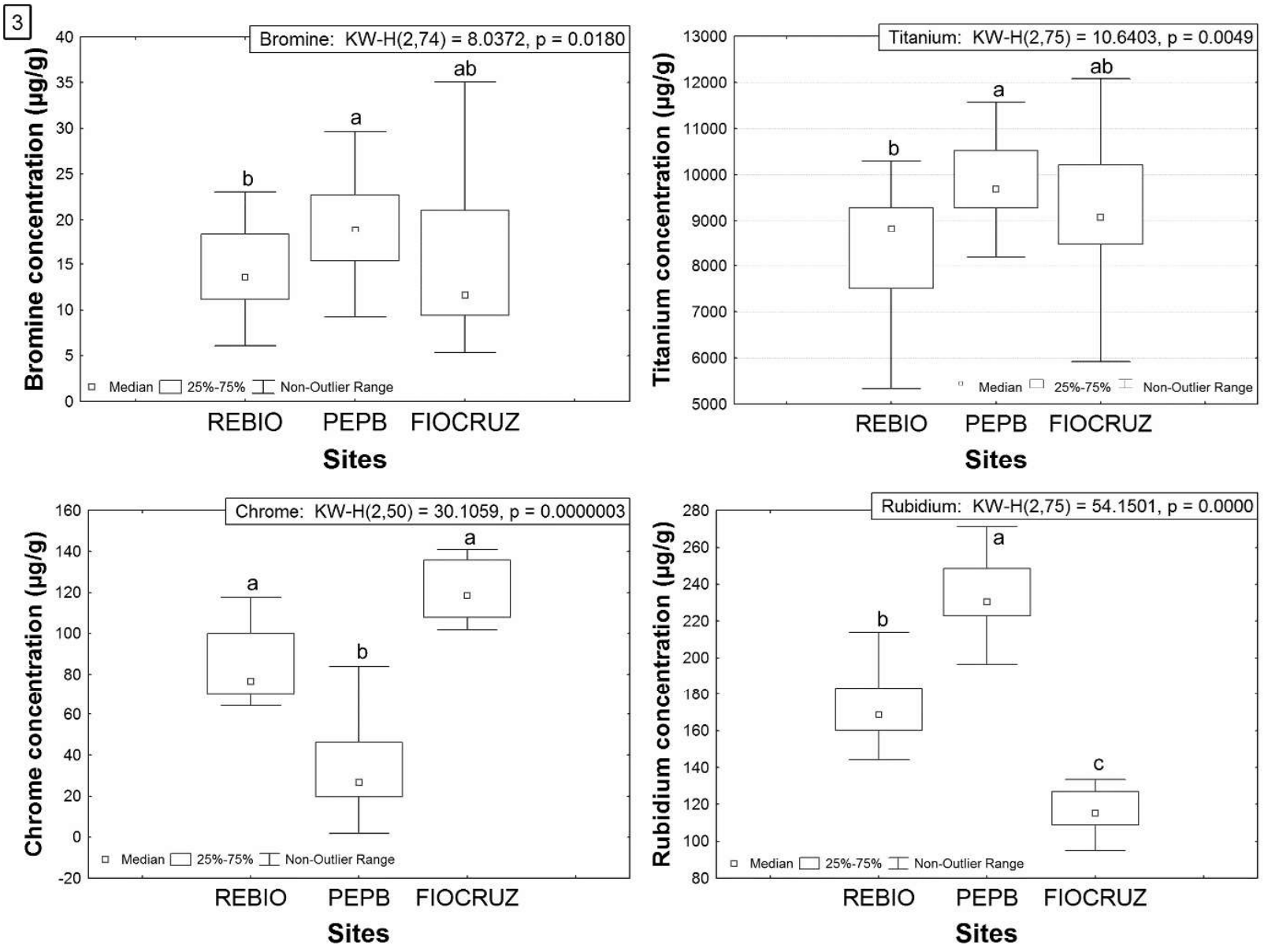

Figure 3 - Box-plots of bromine, titanium, chromium and rubidium soil concentrations of the three study sites. The letters above the box indicate the results of ANOVA and Kruskal-Wallis tests. Different letters indicate statistics differences $* \mathrm{p}<0.05$.

Figura 3 - Box-plots de concentrações de bromo, titânio, cromo e rubídio no solo dos três locais de estudo. As letras acima da caixa indicam os resultados dos testes ANOVA e Kruskal-Wallis. Letras diferentes indicam diferenças estatísticas * $p<0,05$.

In forest ecosystems, among other factors, the high concentration of nutrients has been attributed to the decomposition of organic matter and efficient recycling of nutrients from litter (e.g.: Curvelo et al., 2009; Viera et al., 2013; Bachtold and Melo Júnior, 2015). Thus, it is possible that the litter layer observed only in the TINGUÁ and PEPB forest remnants soils may have an influence on the higher concentration of potassium and manganese in these sites compared to the urban site, FIOCRUZ.

Although we have not explored in this study, the local geology is an important component of the concentration of chemical elements in the soil (e.g.: Freedman, 1995; Kabata-Pendias, 2011). The higher concentrations of rubidium in the forest sites soil, for example, can be attributed to its natural occurrence because this element is a common element of the earth's crust. Rubidium mainly occurs in higher concentrations in heavy clay soils (Saraiva, 2007; Kabata-Pendias, 2011), as are found at TINGUÁ (MMA/IBAMA, 2010) and in soils composed by gneiss and granitic rocks (KabataPendias, 2011), as are found at PEPB (INEA, 2016).

It is not possible to conclude whether the high concentration of niobium in the soil of TINGUÁ is associated with natural sources or anthropic activities. High concentrations of this element have been observed in cambisol and latosol soil types (Melfi et al., 1991; Kabata-Pendias, 2011; Santos, 2013), which are found at 
4
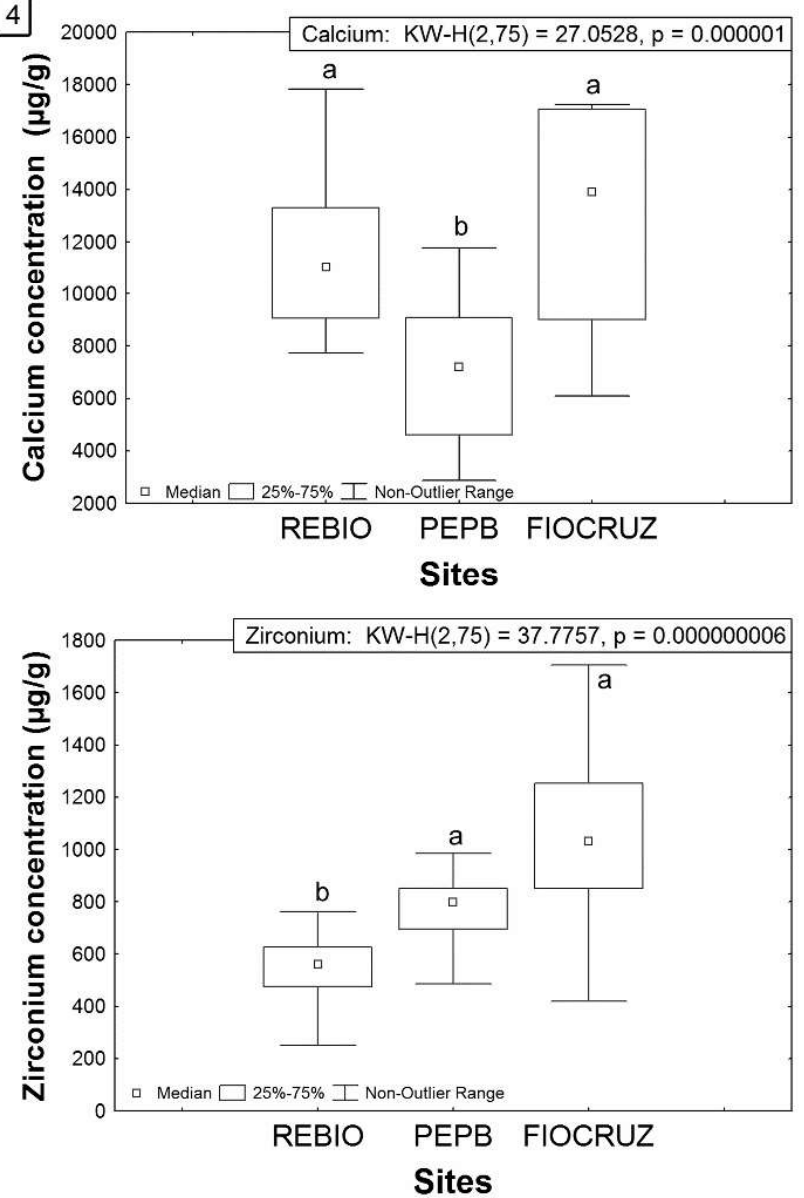
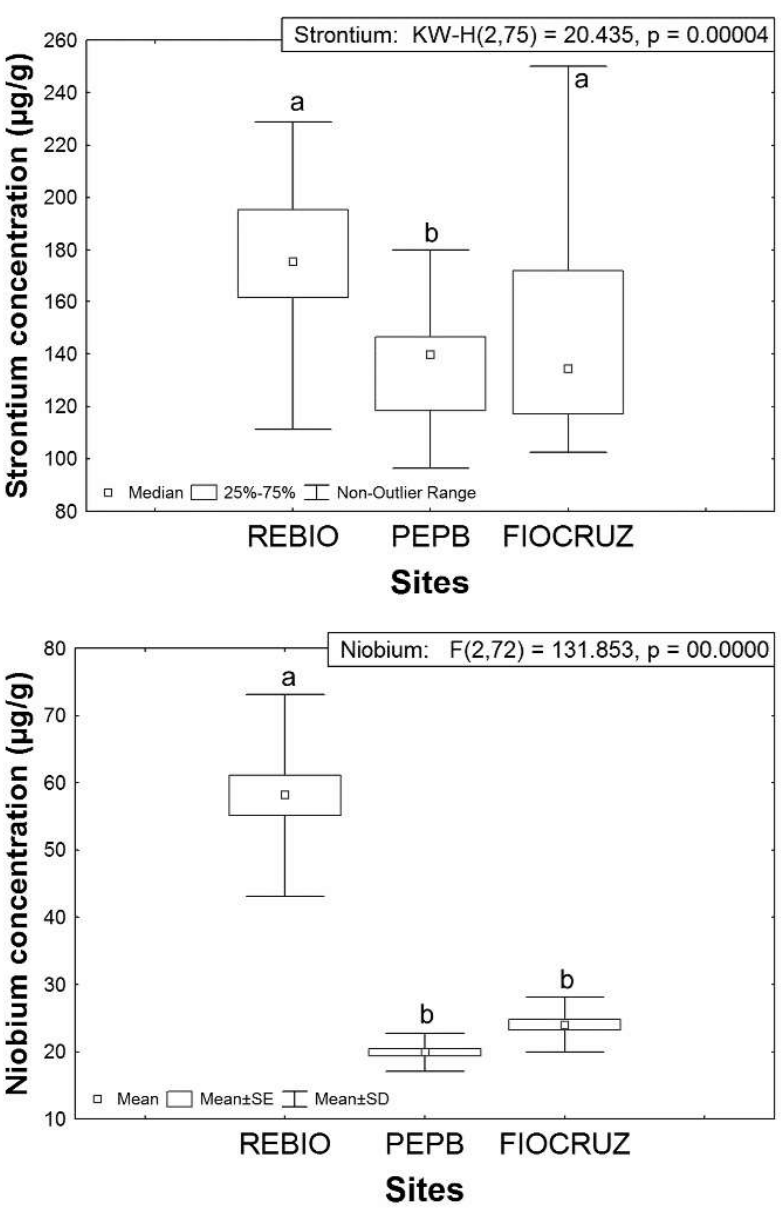

Figure 4 - Box-plots of calcium, strontium, zirconium and niobium soil concentrations of the three study sites. The letters above the box indicate the results of ANOVA and Kruskal-Wallis tests. Different letters indicate statistics differences $* \mathrm{p}<0.05$.

Figura 4 - Box-plot das concentrações de cálcio, estrôncio, zircônio e nióbio no solo dos três locais de estudo. As letras acima da caixa indicam os resultados dos testes ANOVA e Kruskal-Wallis. Letras diferentes indicam diferenças estatísticas * $p<0,05$.

TINGUÁ (MMA/IBAMA, 2010). However, there is an anthropogenic interference that could also explain this result in Reserva Biológica do Tinguá, the occurrence of gas and oil pipelines of the Petróleo Brasileiro S.A. company (Petrobras). There are no records of leakage from these pipelines (MMA/IBAMA, 2010; Araújo et al., 2014), but niobium is widely used in steelmaking, and steel is the main material used for construction oil pipelines and platforms for deepwater oil exploration (Alves and Coutinho, 2015; Tarselli, 2015).

The difference in calcium concentration found between the soils of TINGUÁ and PEPB, and the similarity of the concentrations of this element in the soils of TINGUÁ and FIOCRUZ, may be explained by anthropic contribution. Calcium is an element commonly found in particulate matter emitted into the atmosphere by construction sites (Resende, 2007), and in the solid residues of oil refining (Mariano, 2001). These sources are present in the region where the FIOCRUZ site is located, and a large cement factory a full $\sim 17 \mathrm{~km}$ away can explain the results obtained to TINGUÁ.

Among the chemical elements that were in high concentrations in the soil of FIOCRUZ, nickel, chromium, copper, zinc and lead are of particular interest because of their observed high concentrations and because they are elements with proven toxicity (Freedman, 1995; Nagajyoti et al., 2010; Małkowski et al., 2019). Nickel, copper and zinc are considered micronutrients for plants

\section{Revista Árvore 2021;45:e4504}



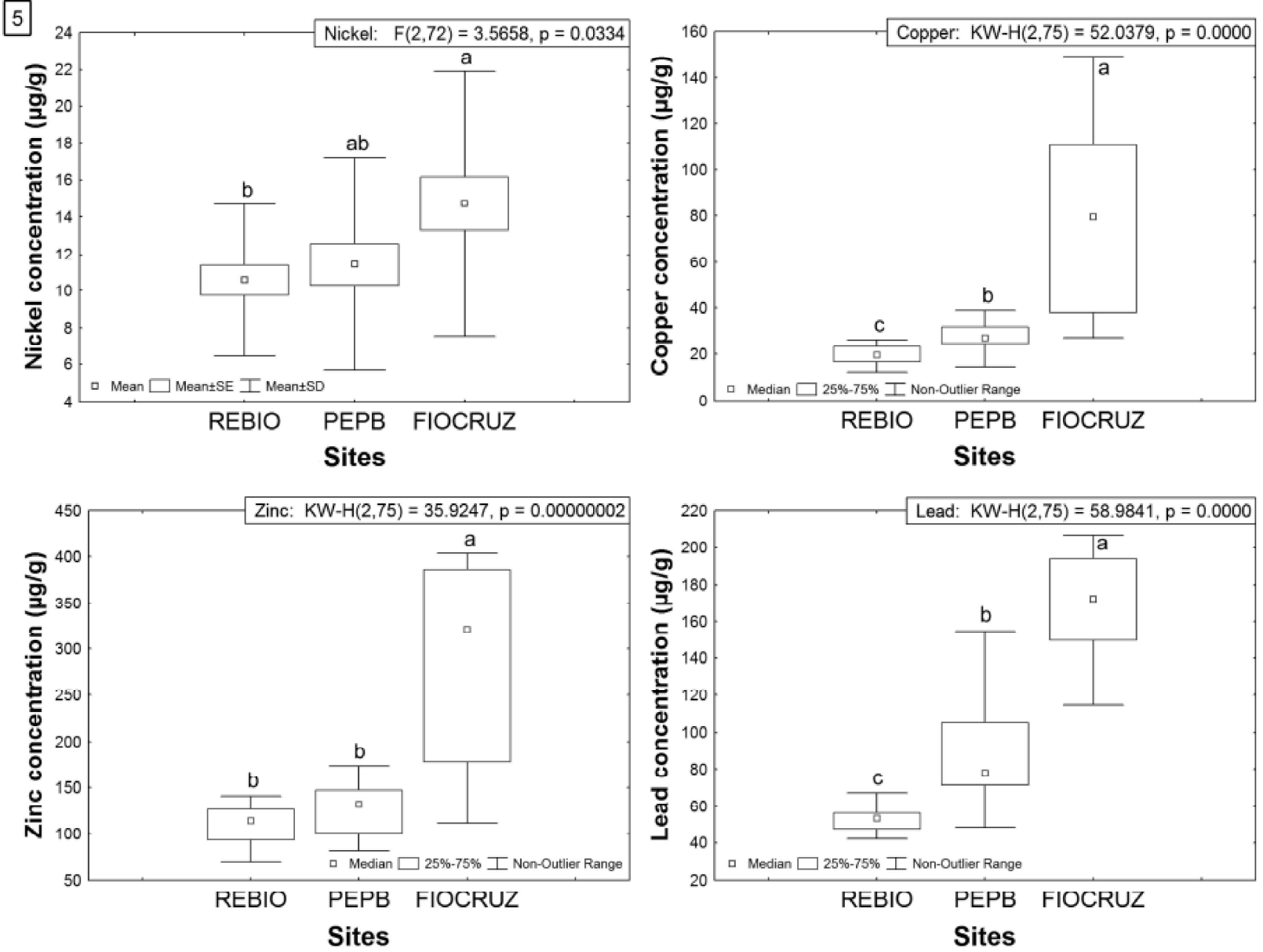

Figure 5 - Box-plots of nickel, copper, zinc and lead soil concentrations of the three study sites. The letters above the box indicate the results of ANOVA and Kruskal-Wallis tests. Different letters indicate statistics differences *p $<0.05$.

Figura 5 -Box-plots de concentrações de níquel, cobre, zinco e chumbo no solo dos três locais de estudo. As letras acima da caixa indicam os resultados dos testes ANOVA e Kruskal-Wallis. Letras diferentes indicam diferenças estatísticas * $p<0,05$.

and in excessive concentrations, such as other elements, they can be toxic (Taiz and Zieger, 2013). These five chemical elements also stood out in other analyses carried out with urban soils in China, Saudi Arabia, Egypt and Brazil (the states of São Paulo and Rio de Janeiro) (e.g.: Duarte and Pasqual, 2000; McAlister et al., 2005; Assirey and El-Shahawi, 2015; Elnazer et al., 2015; Lopes et al., 2015). In studies of air pollution in the city of Rio de Janeiro, these elements were found at high levels in the region of FIOCRUZ (Quiterio et al., 2004; Mcalister et al., 2005; Silva et al., 2008). These elements are also among the major heavy metals observed in particulate matter emitted by vehicles and industries (Mohanraj et al., 2004; Srivastava et al.,
2016). These findings are consistent with our results, given the presence of these sources near FIOCRUZ.

The high concentrations of copper and zirconium observed in the soil of FIOCRUZ can be associated with a variety of sources. Copper is present in fertilizers, sewage and industrial waste, and it is released in the process of corrosion of alloys, such as ducts and electric wires (Kabata-Pendias, 2011; Melo et al., 2016). Zirconium is often found in urban environments because it is one of the major components of cellular batteries (Reidler and Günther, 2003) and is also found in sewage sludge (Sígolo and Pinheiro, 2010). All these factors are present in the urban site, FIOCRUZ (EMOP, 2012), and explain the high concentrations observed.

\section{Revista Árvore 2021;45:e4504}


The high concentrations of lead and zinc found in the three studied sites can be worrying. These elements when bioavailable and in high concentrations can cause serious deleterious effects to microorganisms, animals and plants (Hernandez et al., 2003; Peakall and Burger, 2003; Lukkari et al., 2004; Lukkari et al., 2005; Salazar and Pignata, 2014; Yaqub et al., 2015; Fang et al., 2015). The use of zinc and lead in the automobile parts manufacturing and as catalysts in fossil fuel burning has resulted in increased concentrations of these elements with the expansion of urban centers and an increasing number of vehicles (Kabata-Pendias, 2011; Elnazer et al., 2015; Melo et al., 2016).

Atmospheric deposition is an important mode of pollutants entrance into forest ecosystems (Lovett et al., 2000; Rodrigues et al., 2007; Souza et al., 2017). Heavy metal input, such as zinc and lead, has already been reported for Atlantic Forest remnants of southeastern Brazil, specifically the states of Rio de Janeiro and São Paulo (França et al., 2004; Oliveira et al., 2005; Elias et al., 2006). Such atmospheric deposition can explain the observed high concentrations of these elements in the studied forest remnants. However, the highest concentrations were observed in soil samples from the urban site (FIOCRUZ). High concentrations of these metals have been previously reported for other urban soils (Barcellos et al., 1991; Manta et al., 2002; Wei and Yang, 2010). Therefore, the high concentrations of these two elements indicate a considerable anthropogenic contribution to all study sites.

\section{CONCLUSIONS}

The present study results showed significant differences in the concentration of elements in the soil of the three studied sites. The forest sites soil possessed higher concentrations of potassium and manganese, which according to the literature, can be attributed to the higher production of litter. On the other hand, and as expected, the urban site had higher concentrations of copper, zinc and lead, associated by literature as being common in anthropized environments.

The contribution of anthropogenic activities to increased concentrations of chemical elements found in the soil, such as copper and lead, shown by both differences in the elements concentration among the study sites and by the relationship between concentration and proximity of pollution sources, resulted in a directly proportional concentration gradient.
Although the EDXRF technique is not considered standard in the establishment of quality reference values for soils, the registration these chemical elements and their respective concentrations, according to an urbanization gradient, becomes important for future comparisons.

Though the equipment used provides the total concentrations of each chemical element and not the bioavailability of each one, we highlight that presence of potentially toxic elements in forest soils was an unusual finding and must be considered dangerous because it can have negative consequences for these remnants, hotspots of biodiversity.

\section{ACKNOWLEDGEMENTS}

The authors are grateful to Walter da Silva for the valuable technical assistance, and Fiocruz, PEPB/INEA e Tinguá/ICMBio for research authorizations. The authors thankful to Universidade do Estado do Rio de Janeiro and to Programa de Pós-Graduação em Biologia Vegetal da Universidade do Estado do Rio de Janeiro. The authors also wish to extend their thanks to the Editor-inchief and the anonymous reviewers for their constructive comments. This study was part of $\mathrm{PhD}$ Thesis of the first author and master's dissertation of the second author and was financed by Fundação Carlos Chagas Filho de Amparo à Pesquisa do Estado do Rio de Janeiro (FAPERJ: Program Scholarship E-26/101.439/2012, and financial support E-26/101.459/2010), Coordenação de Aperfeiçoamento de Pessoal de Nível Superior - Brasil (CAPES) - Finance Code 001, Conselho Nacional de Desenvolvimento Científico e Tecnológico (CNPq: research grant 309080/2019-3) and Financiadora de Estudos e Projetos (FINEP - CT-INFRA 01.13.0444.02).

\section{AUTHOR CONTRIBUTIONS}

Thaís Jorge de Vasconcellos and Nattacha dos Santos Moreira: Conceived and designed the analysis; collected and analysis the data; wrote the paper.

Ramon Silva dos Santos and Marcelino José dos Anjos: Contributed data and analysis tools.

Cátia Henriques Callado: Conceived and designed the analysis; wrote the paper.

\section{REFERENCES}

Alves AR, Coutinho AR. The evolution of the niobium production in Brazil. Materials 
Research. 2015;18(1):106-12. doi: https://doi. org/10.1590/1516-1439.276414.

Anjos M, Lopes R, Jesus EF, Assis J, Cesareo R, Barradas CA. Quantitative analysis of metals in soil using X-ray fluorescence. Spectrochim Acta Part B. 2000;55(7):1189-94. doi: 10.1016/S05848547(00)00165-8

Appel C, Ma LQ, Rhue RD, Reve W. Sequential sorption of lead and cadmium in three tropical soils. Environ Pollut. 2008;155(1):132-40. doi: 10.1016/j. envpol.2007.10.026.

Araújo JPC, Silva LM, Silva FAD, Fernandes NF. Previsão de escorregamentos translacionais rasos e área de dutos: estudo de caso do maciço do Tinguá na reserva biológica federal do Tinguá (RJ). Rev Geonorte. 2014;10(1):224-9.

Assirey E, El-Shahawi MS. Assessment of roadside soil pollution by heavy metal ions and correlation to traffic activities in Madina City, Saudi Arabia: Part i. Asian J Chem. 2015;27(3):1160-6. doi: 10.14233/ ajchem.2015.18746.

Bachtold BA, Melo Junior JCF. Plasticidade morfológica de Calophyllum brasiliense Camb. (Calophyllaceae) em duas formações de restinga no sul do Brasil. Acta Biológica Catarinense. 2015;2(2). doi: 10.21726/abc.v2i2.165.

Barcellos C, Rezende CE, Pfeiffer WC. Zn and $\mathrm{Cd}$ production and pollution in a Brazilian coastal region. Marine Pollution Bulletin. 1991;22(11):558 61. doi: 10.1016/0025-326X(91)90896-Z.

Curvelo K, Calasans NA, Lobão DE, Sodré GA, Pereira JM, Mar PCL, et al. Aporte de nutrientes na serapilheira e na água do solo em cacau: cabruca, floresta secundária e pastagem. Agrotrópica.2009;21(1):55-64.

Dai J, Becquer T, Rouiller JH, Reversat G, BernhardReversat F, Lavelle P. Influence of heavy metals on C and $\mathrm{N}$ mineralisation and microbial biomass in $\mathrm{Zn}$-, $\mathrm{Pb}-, \mathrm{Cu}-$, and Cd-contaminated soils. Appl Soil Ecol. 2004;25(2):99-109. doi: 10.1016/j.apsoil.2003.09.003

Duarte RPS, Pasqual A. Avaliação do Cádmio (Cd), Chumbo (Pb), Níquel (Ni) e Zinco ( $\mathrm{Zn}$ ) em solos, plantas e cabelos humanos. Energia na Agricultura. 2000;15(1):46-58.
Elias C, Fernandes EADN, França EJ, Bacchi MA. Seleção de epífitas acumuladoras de elementos químicos na Mata Atlântica. Biota Neotrop. 2006;6(1). doi: 10.1590/S1676-06032006000100010.

Elnazer AA, Salman SA, Seleem EM, Abu El Ella EM. Assessment of some heavy metals pollution and bioavailability in roadside soil of Alexandria-Marsa Matruh Highway, Egypt. Int J Ecol. 2015;2015(1). doi: $10.1155 / 2015 / 689420$.

Empresa de Obras Públicas do Estado do Rio de Janeiro - EMOP. Manguinhos: plano de Desenvolvimento Sustentável. 2012. [accessed: 13 January 2012] Available from: http://www. emop.rj.gov.br/trabalho-tecnico-social/plano-dedesenvolvimento-sustentavel-pds/.

Fang K, Chen D, Gou X, D’Arrigo R, Davi N. Influence of non-climatic factors on the relationships between tree growth and climate over the Chinese Loess Plateau. Glob Planet Change. 2015;132:54-63. doi: https://doi.org/10.1016/j.gloplacha.2015.06.008

França E, Fernandes EADN, Bacchi MA, Saiki M. Native Trees as Biomonitors of Chemical Elements in the Biodiversity Conservation of the Atlantic Forest Native Trees as Biomonitors of Chemical Elements in the Biodiversity Conservation of the Atlantic Forest. Journal of Atmospheric Chemistry. 2004;49(1):579-592. doi: 10.1007/s10874-004$1267-\mathrm{y}$

Freedman B. Environmental ecology: the ecological effects of pollution, disturbance, and other stresses. New York: Academic Press; 1995.

Freitas TA, França MGC, Almeida AAF, Oliveira SJR, Jesus RM, Souza VL, et al. Morphology, ultrastructure and mineral uptake is affected by copper toxicity in young plants of Inga subnuda subs . luschnathiana (Benth.) T.D. Penn. 2015; 22(20):15479-94. doi: 10.1007/s11356-015-4610-8.

Furlan CM, Moraes RM, Bulbovas P, Sanz MJ, Domingos M, Salatino A. Tibouchina pulchra (Cham.) Cogn., a native Atlantic Forest species, as a bio-indicator of ozone: Visible injury. 2008; 152(2):361-365. doi: 10.1016/j.envpol.2007.06.042

Guilherme LRG, Marques JJ, Pierangeli MAP, Zuliani DQ, Campos ML, Marchi G. Elementostraço em solos e sistemas aquáticos. Tópicos 
em Ciências do Solo. 2005;4(3):345-90. doi: 10.13140/2.1.4821.1524.

Hernandez L, Probst A, Probst JL, Ulrich E. Heavy metal distribution in some French forest soils: Evidence for atmospheric contamination. Sci Total Environ. 2003;312(1-3):195-219. doi: 10.1016/ S0048-9697(03)00223-7.

Instituto Estadual do Ambiente - INEA. Plano de Manejo do Parque Estadual da Pedra Branca. 2016. [accessed: 17 March 2016]. Available from: http://www.femerj.org/wp-content/uploads/Planode-manejo-do-Parque-Estadual-da-Pedra-BrancaPEPB-2.pdf.

Joly CA, Metzger JP, Tabarelli M. Experiences from the Brazilian Atlantic Forest: ecological findings and conservation initiatives. New Phytol. 2014; 204(3):459-73. doi: 10.1111/nph.12989.

Kabata-Pendias A. Trace elements in soils and plants. Boca Raton: CRC Press; 2011.

Lopes M, Santos A, Camargo C, Bulbovas P, Giampaoli P, Domingos M. Soil chemical and physical status in semideciduous Atlantic Forest fragments affected by atmospheric deposition in central-eastern São Paulo State, Brazil. iForest - Biogeosciences For. 2015;8(6):798-808. doi: 10.3832/ifor1258-007.

Lovett GM, Traynor MM, Pouyat RV, Carreiro MM, Zhu WX, Baxter JW. Atmospheric Deposition to Oak Forests along an Urban - Rural Gradient. Environ. Sci. Technol. 2000;34(20):4294-300.

Lukkari T, Taavitsainen M, Soimasuo M, Oikari A, Haimi J. Biomarker responses of the earthworm Aporrectodea tuberculata to copper and zinc exposure: differences between populations with and without earlier metal exposure. Environ Pollut. 2004;129(3):377-86. doi: 10.1016/j. envpol.2003.12.008.

Lukkari T, Aatsinki M, Vaisanen A, Haimi J. Toxicity of copper and zinc assessed with three different earthworm tests. Appl Soil Ecol. 2005;30(2):133146. doi: 10.1016/j.apsoil.2005.02.001

Mahajan NC, Mrunalini K, Prasad KSK, Naresh RK, Sirisha L. Soil quality indicators, building soil organic matter and microbial derived inputs to soil organic matter under conservation agriculture ecosystem: a review. Int J Curr Microbiol Appl Sci. 2019;8(2):1859-79. doi: 10.20546/ ijcmas.2019.802.218.

Małkowski E, Sitko K, Zieleźnik-Rusinowska P, Gieroń Ż, Szopiński M. Heavy Metal Toxicity: Physiological Implications of Metal Toxicity in Plants. In: Sablok G, editor. Plant Metallomics and Functional Omics. Cham: Springer; 2019. p. 253301. doi: 10.1007/978-3-030-19103-0_10

Manta D, Angelone M, Bellanca A. Heavy metals in urban soils: a case study from the city of Palermo (Sicily), Italy. Sci Total Environ.2002;300(1-3):229-43. doi: 10.1016/S00489697(02)00273-5

Mariano JB. Impactos ambientais do refino de petróleo. [Dissertação]. Rio de Janeiro, RJ. Universidade Federal do Rio de Janeiro; 2001.

McAlister JJ, Smith BJ, Neto JB, Simpson JK. Geochemical distribution and bioavailability of heavy metals and oxalate in street sediments from Rio de Janeiro, Brazil: A preliminary investigation. Environ Geochem Health. 2005;27(5-6):429-41. doi:10.1007/s10653-005-2672-0.

Melfi AJ, Soubiès F, Toledo-Groke MC.

Comportamento do nióbio nas alterações das rochas do complexo alcalino-carbonatítico de Tapira, Minas Gerais, in: SBGq, Congresso Brasileiro de Geoquímica. Anais I, São Paulo (SP), 1991.

Melo GMP, Melo VP, Melo WJ. Metais pesados no ambiente decorrente da aplicação de lodo de esgoto em solo agrícola. [accessed 03 April 2016] Available from: http://www.mma.gov.br/port/conama/reunalt. cfm?cod_reuniao $=490$.

MMA/IBAMA. Plano de Manejo da Reserva Biologica do Tinguá, RJ. 2010.

Mohanraj R, Azeez PA, Priscilla T. Heavy metals in airborne particulate matter of urban Coimbatore. Arch Environ Contam Toxicol. 2004;47(2):162-7. doi: 10.1007/s00244-004-3054-9

Nagajyoti PC, Lee KD, Sreekanth TVM. Heavy metals, occurrence and toxicity for plants: A review. Environ Chem Lett. 2010;8(3):199-216. doi: 10.1007/s10311-010-0297-8. 
Oliveira RR, Lúcia C, Magalhães AC, Firme RP. Ciclagem de metais pesados na serapilheira de uma floresta urbana no Rio de Janeiro. 2005;12(1):50-6.

Peakall D, Burger J. Methodologies for assessing exposure to metals: speciation, bioavailability of metals, and ecological host factors. Ecotoxicol Environ Saf. 2003;56(1):110-21. doi: 10.1016/ S0147-6513(03)00055-1.

Pierangeli MAP, Guilherme LRG, Curi N, Anderson SJ, Lima JM. Adsorção e dessorção de cádmio, cobre e chumbo por amostras de latossolos pré-tratadas com fósforo. Rev Bras Ciências do Solo. 2004;28:377-84. doi:10.1590/S010006832004000200016 .

Quiterio SL, Sousa da Silva CR, Arbilla G, Escaleira $\mathrm{V}$. Metals in airborne particulate matter in the industrial district of Santa Cruz, Rio de Janeiro, in an annual period. Atmos Environ. 2004;38(2):321-31. doi: 10.1016/j.atmosenv.2003.09.017.

Reidler NMVL, Günther WMR. Impactos ambientais e sanitários causados por descarte inadequado de pilhas e baterias usadas. Revista Limpeza Pública 2003; 60: 20-26.

Resende F. Poluição atmosférica por emissão de material particulado: avaliação e controle nos canteiros de obras de edifícios. [Dissertação]. São Paulo, SP. Universidade de São Paulo; 2007.

Rezende CL, Scarano FR, Assad ED, Joly CA, Metzger JP, Strassburg BBN, et al. From hotspot to hopespot: an opportunity for the Brazilian Atlantic Forest. Perspect Ecol Conserv. Associação Brasileira de Ciência Ecológica e Conservação. 2018;16(4):208-14. doi: 10.1016/j. pecon.2018.10.002.

Rodrigues RDAR, Mello WZ, Souza PA. Aporte atmosférico de amônio, nitrato e sulfato em área de floresta ombrófila densa montana na Serra dos Órgãos, RJ. Quim Nova. 2007;30(8):1842-8. doi: $10.1590 /$ S0100-40422007000800009

Rodríguez-Eugenio N, McLaughlin M, Pennock D. Soil Pollution: a hidden reality. Rome: FAO, 2018. ISBN 9789251305058

Romero-Freire A, Sierra Aragón M, Martínez Garzón FJ, Martín Peinado FJ. Is soil basal respiration a good indicator of soil pollution? Geoderma. 2016;263:132-9. doi:10.1016/j. geoderma.2015.09.006.

Salazar MJ, Pignata ML. Lead accumulation in plants grown in polluted soils. Screening of native species for phytoremediation. J Geochemical Explor. 2014;137:29-36. doi: 10.1016/j.gexplo.2013.11.003.

Santos WH. Estudo sobre o uso do pentacloreto de nióbio em reações multicomponentes para a síntese de derivados de 4-aril-3,4- di-hidrocumarinas. [Dissertação]. Bauru, SP. Universidade Estadual Paulista; 2013.

Santos RS, Sanches FACRA, Leitão RG, Leitão CCG, Oliveira DF, Anjos MJ, Assis JT. Multielemental analysis in Nerium Oleander L. leaves as a way of assessing the levels of urban air pollution by heavy metals. Applied Radiation and Isotopes. 2019; 152: 18-24. doi10.1016/j. apradiso.2019.06.020

Saraiva MAM. Metais Pesados em amostras de horizontes superficiais de solos como indicadores ambientais na bacia hidrográfica do rio Taquarizinho - Campo Grande/MS. [Dissertação]. Campo Grande, MS. Universidade Federal de Mato Grosso do Sul; 2007.

Scarano FR, Ceotto P. Brazilian Atlantic forest: impact, vulnerability, and adaptation to climate change. Biodivers Conserv. 2015;(24):2319-31. doi: 10.1007/s10531-015-0972-y

Sígolo JB, Pinheiro CHR. Lodo de esgoto da ETE barueri - SP: Proveniência do enxofre elementar e correlações com metais pesados associados. Geol USP - Ser Cient. 2010;10(1):39-51. doi: 10.5327/ Z1519-874X2010000100004.

Silva LID, Souza Sarkis JE, Zotin FMZ, Carneiro MC, Neto AA, Silva A dos SAG, et al. Traffic and catalytic converter - related atmospheric contamination in the metropolitan region of the city of Rio de Janeiro, Brazil. Chemosphere. 2008;71(4):677-84. doi: 10.1016/j. chemosphere.2007.10.057.

Solé VA, Papillon E, Cotte M, Walter P, Susini J. A multiplatform code for the analysis of energydispersive X-ray fluorescence spectra. Spectrochim. Acta, Part B. 2007;62(1):63-68. doi: 10.1016/j. 
sab.2006.12.002.

Souza PA, Mello WZ, Silva JJN, Rodrigues RDAR, Conceição MCG. Atmospheric wet, dry and bulk deposition of inorganic nitrogen in the Rio de Janeiro state. Revista Virtual de Quimica. 2017;9(5):205266. doi: 10.21577/1984-6835.20170122

Srivastava D, Goel A, Agrawal M. Particle Bound Metals at Major Intersections in an Urban Location and Source Identification Through Use of Metal Markers. Proc Natl Acad Sci India Sect A - Phys Sci. Springer India; 2016;86(2):209-20. doi: 10.1007/ s40010-016-0268-y

Taiz L., Zeiger E. Fisiologia Vegetal. 5th ed. Porto Alegre: Artmed, 2013.

Tarselli M. Subtle niobium. Nat Chem. 2015;7(2):180. doi /10.1038/nchem.2164.

Tume P, González E, King RW, Cuitiño L, Roca N. Distinguishing between natural and anthropogenic sources for potentially toxic elements in urban soils of Talcahuano, Chile. J Soils Sediments. 2017;18: 2335-2349. doi:10.1007/s11368-017-1750-0.

Viera M, Schumacher MV, Caldeira MVW. Dinâmica de decomposição e nutrientes em plantio de Eucalyptus urophylla $\times$ Eucalyptus globulus no sul do Brasil. Floresta e Ambient. 2013;20(3):35160. doi: 10.4322/floram.2013.021.

Wei B, Yang L. A review of heavy metal contaminations in urban soils, urban road dusts and agricultural soils from China. Microchem J. 2010;94(2):99-107. doi:10.1016/j. microc.2009.09.014

Wuana RA, Okieimen FE. Heavy Metals in Contaminated Soils: a review of sources, chemistry, risks and best available strategies for remediation. International Scholarly Research Notices. 2011; 2011:1-20. doi: 10.5402/2011/402647.

Yaqub M, Akhtar R, Muhammad U, Bibi S, Talimand H, Aslam M, et al. Effects of Road Side Pollution on Vegetation-A Mini-Review. J Bio-Molecular Sci. 2015;3(3-4):97-106.

Zar JH. Biostatistical Analysis. 5th ed. New Jersey: Pearson, 2010.

Zhu Z, Sun G, Bi X, Li Z, Yu G. Identification of trace metal pollution in urban dust from kindergartens using magnetic, geochemical and lead isotopic analyses. Atmos Environ. 2013;77:9-15. doi:10.1016/j.atmosenv.2013.04.053 